\title{
Strategies for Improving Basic Japanese Grammar Skills Through Acrostic Techniques
}

\author{
Lady Diana Yusri ${ }^{1, *}$ Idrus $^{2}$ \\ ${ }^{1,2}$ The Japanese Department, Andalas University \\ ${ }^{*}$ Corresponding author. Email: ladydianayusri@hum.unand.ac.id
}

\begin{abstract}
This article is about using acrostic techniques to improve understanding of basic Japanese grammar. This research focuses more on changing the form of $\sim t e$ in Japanese. The subjects of this study were 40 students taking The Introductory Japanese Language course. The implementation of this learning model is divided into four stages. The first stage is material preparation by the Teacher. The second stage is the activity implementation stage. The Teacher performs acrostic techniques on the $\sim$ te form and asks students to sing it. The third stage is the evaluation stage. At this stage, the Teacher provides training to students to see the extent of their understanding of the material. The fourth stage is correction and analysis. At this stage, the questions carried out by students were corrected and analyzed in order to find out the forms that were difficult to understand. This learning technique can also help students learn more effectively. The effectiveness can we see from the results obtained quite well. So it can be said that this learning model can do the basic level of japanese grammar learning.
\end{abstract}

Keywords: grammar, basic level, learning Japanese, acrostic technic

\section{INTRODUCTION}

Learning is a process of effort by a person to obtain a whole new change in behavior, as a result of his own experience in interacting with his environment. Meanwhile, teaching is related to the activities carried out by the teacher. The purpose of learning is that teachers provide experiences that include knowledge, skills, values, and norms that function as controllers of student attitudes and behavior by Sugandi [1]. So, in a learning process, there is an interaction between learners and teachers.

Research is needed to refine previous learning activities further. In this Classroom Action research activity, the author will explain learning in the Introduction to the Japanese Language course. The purpose of this research is to find suitable teaching and easy to understand by learners.

The contribution of this course in Introduction to the Japanese Language is significant. It is related to students' competence and knowledge for Japanese language skills after completing their studies. Therefore, it is necessary to have a fun learning process, and students can apply it quickly. In this classroom action activity, the researcher tries to improve learning by using acrostic techniques.

Acrostic technique learning is by remembering the first letter of each word that will be memorized by the learners. However, sometimes it does not always use the first letter and does not always produce an abbreviation in the form of a single word, but the information that memorized in an acrostic can be in the form of a particular sentence or phrase by Harianti [2] and Sutrisno[3].

Learning using acrostic techniques can also be done by making acrostic sentences, namely making puns. According to our tastes, but still take the front letter, and it has a meaning, the meaning of a play or figurative meaning is a meaning that we make by ourselves.

The learning model with acrostic techniques is one way to make learning more student-centered or better known as Student-Centered Learning. Johnson [4] states that this learning model reduces direct interaction but uses 
one-on-one interactions. The point is that students can study the material provided by the lecturer at any time. This learning can take advantage of students' activeness to memorize phrases and sentences to understand Japanese grammar. Besides, technology, such as PowerPoint or videos, is also used to support learning. Students can use it by utilizing online and offline media. Several previous researchers have previously carried out research using this acrostic technique in Japanese language learning; here is the explanation. Pujiono [5] conducted a study on using acrostic techniques by focusing on Japanese vocabularies, such as names of days and numbers in Japanese. The result obtained by Pujiono is that learning Japanese vocabulary using acrostic techniques is a useful way to improve skills in the learning process of vocabulary in Japanese.

Besides, Helmi [6] also conducted research using acrostic techniques. This research aimed to find out whether or not vocab acrostic effective in teaching Vocabulary at MTs. Islam Selaparang Putra Kediri, West Lombok. This research is experimental. The design used was one group pre-test post-test design. The simple was all population of the second-grade students that consisted of 28 students. It can conclude that Vocab Acrostic is useful in teaching Vocabulary at MTs.

The difference between the author did and others the researcher did first was that the author tried to focus on Japanese grammar. In contrast, the previous researcher focused more on improving Japanese vocabulary.

The following is an explanation of things that can be of concern in learning using acrostic techniques.

1. Change the role of the Teacher. In traditional classrooms, the teacher acts as a mentor. However, in grammar learning with this acrostic technique, the Teacher in traditional classes becomes a mentor, but in this class, the Teacher is no longer the center of learning. The Teacher serves as a facilitator who provides a way for students to remember Japanese grammar more easily. 2. Changing the role of students. Teachers can make students more active by utilizing technology. Teachers can provide learning resources that can enable students to study independently. It hoped that students could control their time better.

3. Reallocation of class time. This learning model reduces the Teacher's time in providing a material explanation. The student gives more time to increase understanding outside the classroom in a way they like.

\section{METHODS}

Learning Japanese grammar using acrostic techniques is applied to the Introduction to Japanese course. This course included in elective courses in the Mechanical Engineering Study Program, Andalas University. Students introduced the Japanese language, this course, including courses related to Japanese language skills. Forty students take part in this class.
Learning in this course is expected to influence facing the world of work later. If students later work in Japanese companies or collaborate with Japanese people, they expected to communicate and know Japanese work cultures. Therefore, this subject's learning directed at using everyday Japanese using basic grammar, which will then be practiced in the form of conversation and writing for the basic level.

This course's learning objective is to understand and analyze sentence patterns in Japanese according to the subject studied. Besides, students expected to learn independently. Furthermore, students can also develop their ICT skills, such as operating computers to make assignments. This is done so that students can develop interpersonal skills.

The expected learning outcomes are after taking this course. After taking this course, students can explain and use the sentence patterns they learn, such as sentence patterns that use verbs, wish forms, order forms, and others - the Using of nouns, adjectives, and particles in sentences, using verbs according to their change. Also, students can improve their vocabulary skills in Japanese.

The learning method previously used was that students listen to explanations of grammar learned from the lecturer, then students do the exercises provided in the handbook. Next, students try to make sentences with the grammar they learn. The student handbook used is the Marugoto Japanese Language and Culture book written by Kijima et al [7]. The approach taken so far is Student-Centered Learning (SCL), which is more student-centered. However, there were still problems in the lecture as a whole. The problem is that when answering exams, there are still many students who cannot answer questions well; this means that their ability to use grammar is still not right. This is because students only learn Japanese once a week for 1 hour 40 minutes.

The lesson discussed in this paper is Japanese grammar, a sentence that states a request for $\sim$ te kudasai. However, to study this pattern, one must master the changing of the $\sim$ te form. The pattern will be using acrostic techniques.

In connection with the student assessment, it is carried out on the answers to the questions worked on and the process of understanding the grammar of the form that is carried out. Furthermore, when students try to understand grammar with sentence examples while increasing vocabulary in Japanese.

\section{RESULTS AND DISCUSSION}

The implementation of learning activities using acrostic techniques will be carried out using learning with social media and face-to-face meetings. Lecturers act as course designers and provide input to students. In the implementation of this action research, the writer divides the activities into four stages. The following is an explanation of each stage. 
Lectures conducted using acrostic techniques. The following are the steps that the researcher has done.

\subsection{Preparation}

This stage will be carried out into two steps. First, the lecturer will provide questions or pictures related to the topic so that students become interested in listening to the themes and grammar being studied. Second, the lecturer provides general instructions regarding the grammar to be studied. Namely, the Teacher or researcher explains the overall material taught to students in a class. When introducing a new grammar, the Teacher explains acrostic techniques to make it easier to memorize the grammar taught.

Implementing acrostic techniques is carried out in learning Japanese grammar when asking for help from others, using the $\sim$ te kudasai pattern. To understand and use these sentence patterns, students must be able to change verbs into the $\sim$ te form.

The lecturer prepares the audio that sent to the group WhatsApp. This audio contains chants of Japanese verb acrostics. Here are the lyrics of the song.

\section{"ICHIRI TTE NIBIMI NDE KI ITE GI IDE SHI SHITE"}

Students asked to memorize the above lyrics before learning is carried out. Students can change the rhythm of the singing of the song. Give questions or pictures related to the topic so that students become interested in listening to the themes being studied. Second, the lecturer provides vocabulary clues related to the text to be heard.

\subsection{Implementation}

This implementation will be divided into two steps. First, the lecturer will provide an explanation of grammar. Second, the lecturer provides input on media that can be used to understand what is being learned.

The Teacher or researcher here must explain that the acrostic technique in question is a technique of remembering by taking the first, middle, or back letter of each vocabulary to be memorized or memorized. But usually to make things easier, namely by taking the letters that are in the vocabulary.

In the implementation of this lecture, the lecturer explains verbs in Japanese first. To make the $\sim$ te form in Japanese, students must first understand the three verbs of verbs in Japanese and how they form changes. The focus is mostly done on the group I because there are quite many changes in the verb. The following is a brief explanation of Japanese verbs in Kokuritsu Kokugo Kenkyuujo in Sutedi (2020: 9) [8].

Verbs in Japanese divided into three groups

1. Verb group I, which called godankatsuyoudoushi because it has five changes

2. Verb group II, which called ichidankatsuyoudoushi because it has one change
3. Verb group III, which called henkakukatsuyoudoushi because the change is irregular.

The change in the form of $\sim t e$ is an incomplete verb which must be followed by a certain word according to its purpose and purpose. The following is an explanation of the $\sim t e$ form in Japanese.

\author{
Verb group I \\ Kaimasu 'Bought' $\longrightarrow$ Katte \\ Tachimasu 'Stand up' $\longrightarrow$ Tatte \\ Hashirimasu 'Run' $\longrightarrow$ Hashitte \\ Shinimasu 'died' $\longrightarrow$ Shinde \\ Asobimasu "Playing" $\longrightarrow$ Asonde \\ Yomimasu "Read" $\longrightarrow$ Yonde \\ Kakimasu 'Writing' $\longrightarrow$ Kaite \\ Oyogimasu "Swimming" $\longrightarrow$ Oyoide \\ Hanashimasu "Talking" $\longrightarrow$ Hanashite
}

This group I verb is the one that has the most changes, and this is what is made acrostic. How to make the acrostic is by taking Japanese characters before $\sim$ masu.

The acronym of the form $\sim t e$ is as follows:

"Ichiri Tte, Nibimi Nde, Ki Ite, Gi Ide, Shi Shite"

To make it easier for students to remember the acronym above, sing it with a melody that the student likes.

Verb group II

Tabemasu 'Eat' $\longrightarrow$ Tabete

Nemasu 'Sleeping' $\longrightarrow$ Nete

Okimasu 'Wake up' $\longrightarrow$ Okite

Mimasu 'Seeing' $\longrightarrow$ Mite

For group II, changing the shape of $\sim$ te can be done by removing $\sim$ masu and adding $\sim t e$. The change in group II is only in the letters before $\sim$ Masu, namely $\sim e$ or $\sim i$. So, students can remember it.

Verb group III

Kimasu 'Come' $\longrightarrow$ Kite 
Shimasu "Doing" $\longrightarrow$ Shite

Benkyoushimasu 'Learn' $\longrightarrow$ Benkyoushite

Group III verbs consist only of kimasu, shimasu and nouns to which shimasu added. Change the shape of $\sim t e$ by removing the masu shape and adding te.

After this explanation, the lecturer invited the students to sing the $\sim$ te form, and practice using the $\sim$ te form with various verbs.

\section{3. Evaluation}

This evaluation process is carried out by asking students to practice by changing the $\sim$ te form of various verbs. Students are asked to do exercises. From this exercise, one of the assessments can be obtained.

Assessment is an activity to measure the quality of students' knowledge, skills, attitudes, or all three, resulting from the learning process by Mansyurdin et al [9]. In addition, assessment is a process for making decisions using information obtained through measuring good learning outcomes using test and non-test instruments by Zainul and Nasution [10]. So, we can understand that the assessment is a measurement of the learning outcome process, which components include testing and the learning process.

One of the parameters of this learning model's success or failure is to see the value distribution of these students. The following is a table of the value distribution of 40 students.

Table 1. Distribution of student scores in the Introduction to the Japanese language course

\begin{tabular}{|l|l|l|l|}
\hline No & Value & $\begin{array}{l}\text { Number of } \\
\text { Student }\end{array}$ & $\begin{array}{l}\text { Percentag } \\
\mathrm{e}\end{array}$ \\
\hline 1 & 100 & 19 & 47,5 \\
\hline 2 & 95 & 13 & 32,5 \\
\hline 3 & 90 & 5 & 0,125 \\
\hline 4 & 85 & 2 & 0,05 \\
\hline 5 & 80 & 1 & 0,025 \\
\hline
\end{tabular}

From the distribution of student scores above, it can be concluded that this learning technic is considered successful if students who take good classes get a score with a distribution of 80 to 100. Observation data obtained through student activity observation sheets used to see the process and development of activities during learning.

\subsection{Correction and Analysis}

The process of correction and analysis carried out with due observance of which questions are corrected and analyzed, which are still not understood by students. There are several notes about the mistakes made, namely, in changing the form of $\sim t e$, which turned into nomimasu to nonde, as well as in the form of $\sim$ te which became ite like kakimasu to kaite.

After students understand the change in the $\sim$ te form, then proceed with explaining the $\sim$ te kudasai pattern. This pattern aims to convey requests or ask for help from others.

Iori, et al. [11]. For example, in the sentence:

\section{Koko ni namae o kaitekudasai.}

'Please enter your name here.'

In addition, to train students, exercise is carried out while imitating the verb's meaning [7], as an example.

\section{Hon o yonde kudasai}

'Please read the book.'

\section{Hon o mite kudasai.}

'Please see the book.'

Students are very enthusiastic about practicing movements using their gesture such as reading books and putting their hands on their eyes.

At the end of the lecture, to see student responses to this model. Students will be asked whether they find it easier or more difficult to understand grammar with this learning model. And the most important thing is the advantages and disadvantages of this method that students feel in lectures. This is important for the improvement of future lectures.

At the end of the lecture, a questionnaire will distributed to see the student's response to the learning method with this learning model with acrostic techniques. The advantages and disadvantages of the acrostic technic learning models.

1. Short sentence patterns so easy to remember.

2. Can read the description of sentence patterns learned on the cellphone

3. Can better understand sentence patterns from the comments of other students in the group.

4. The sentence patterns sing and make are more fun.

In addition to students' advantages, there are several inputs by students that should be considered for further learning.

1. Still confused about the forms of the same $\sim$ te patterns.

2. Availability of quotas on student cellphones 
3. Lack of opportunities for students to use sentences in conversation.

\section{CONCLUSION}

The application of acrostic techniques to improve Japanese vocabulary carried out in four stages: preparation, implementation, namely by explaining the material, evaluating by giving exercises, and the final stage of correcting and analyzing the activities carried out. Based on the research, it can improve students' ability to remember Japanese patterns. Therefore this technique can be used as an alternative method that can be practiced by other teachers. In addition, based on students' responses, learning with this technique is fun because grammar patterns are easier to remember, and students can be more independent.

This acrostic technique needs to more develop in learning Japanese both in terms of vocabulary and grammar. Therefore, there needs to be further research.

\section{ACKNOWLEDGMENTS}

This work was supported by The Andalas University Educational Development and Quality Assurance Institute for the funding of this research.

\section{REFERENCES}

[1] Sugandi, Ahmad, et al. Belajar dan Pembelajaran. Semarang: IKIP Press. 2000. pp. 25.

[2] Harianti, Deasy. Metode jitu meningkatkan daya ingat (memory power). Jakarta: Tangga Pusaka. 2008. pp. 57.

[3] Sutrisno. Memanfaatkan Teknik-Teknik Teruji untuk Membaca Lebih Cepat dan Mengingat secara Maksimal. Jakarta: Gramedia Pusaka Indonesia. 2008. pp 31.
[4] Johnson, Graham Brent. 2013. Student Preception of The Flipped Classroom. Colombia. The University of British Colombia. Thesis. Doi :10.14288/1.0073641

[5] Pujiono, Muhammad. Penguasaan Kosakata Bahasa Jepang Melalui Teknik Akrostik Pada Mahasiswa Tingkat I Program Studi Sastra Jepang Universitas Sumatera Utara. Prosiding Seminar Nasional yang diselenggarakan Program Studi Pendidikan Bahasa Jepang Universitas Muhammadiyah Yogyakarta atas kerja sama dengan Asosiasi Studi Pendidikan Bahasa Jepang Indonesia (ASPBJI) Korwil JatengDIY dan The Japan Foundation Jakarta. 2017

[6] Helmi, Muhammad. The Effectiveness Of Vocab Acrostic Strategy In Teaching Vocabulary Mastery. Journal of Languages and Language Teaching, Vol. 5, No. 2, November. 2017

[7] Kijima, Hiromo, Shibahara Tomoyo, dan Hatta Naomi. Marugoto Bahasa dan Kebudayaan Jepang A 1. Jepang: Sanshusha Publishing. 2016

[8] Sutedi, Dedi. 2020. Verba Bahasa Jepang. UPI Press: Jawa Barat. 2020 pp 9-11

[9] Manyurdin dkk. Panduan Praktis Pelaksanaan Student Centered Learning (SCL). Lembaga Pengembangan Pendidikan dan Penjaminan Mutu (LP3M) Universitas Andalas. 2014. pp. 52.

[10] Zainul Asmawi dan Noehi Nasution. Penilaian Hasil Belajar. Jakarta: PAU-PPAI, Universitas Terbuka. 2001. pp.8.

[11] Iori Isao, Takanashi Shino, Nakanishi Kumiko, and Yamada Toshihiro. Shokyu o Oshieruhitono Tameno Nihongo Bunpo Handbook. 3A Corporation. Japan. 2000. pp. 148. 